\title{
해상기상탑과 윈드 라이다의 높이별 풍황관측자료 비교 A Comparison of Offshore Met-mast and Lidar Wind Measurements at Various Heights
}

\author{
김지영* · 김민석* \\ Ji Young Kim* and Min Suek Kim*
}

\begin{abstract}
요 지 : 풍력 개발을 위한 해상기상탑은 초기 설치비와 유지보수비가 크기 때문에 윈드 라이다와 같은 원격관측장 비를 이용하여 기상탑을 대체할 필요가 있다. 본 연구에서는 해상기상탑에서 윈드 라이다를 동시 운영하고 수집된 풍속 및 풍향의 관측결과를 상호 비교하여 윈드 라이다의 적용성을 검증하였다. 높이별 풍속 및 풍향 관측결과 두 자료간의 크기 및 경향 등의 통계적 특성 차이는 거의 없으며, 기상탑 관측자료는 구조물 차폐영향에 의한 오차가 발생하는 반면, 윈드 라이다는 오차가 없는 보다 정확한 자료를 얻을 수 있는 것을 확인하였다.
\end{abstract}

핵심용어 : 해상기상탑, 윈드 라이다, 풍황관측, 풍속, 풍향

\begin{abstract}
There is a need to substitute offshore met-mast with remote sensing equipment such as wind lidar since the initial installation and O\&M costs for offshore met-mast are quite high. In this study, applicability of wind lidar is verified by intercomparison test of wind speed and direction data from offshore met-mast and wind lidar for simultaneous operational period. Results at various heights show no statistical difference in trend and size and data from wind lidar is found to be more accurate and have less error than data from offshore met-mast where error from structural shading effect is significant.
\end{abstract}

Keywords : offshore met-mast, wind lidar, wind measurement, wind speed, wind direction

\section{1. 서 론}

풍력 개발을 위해서는 사업 타당성 평가 및 기기 설계를 위 한 대상 지역의 정확한 높이별 풍황 등의 기상환경 관측과 분 석이 필요하다. 이를 위하여 풍력단지 개발자는 높이 $100 \mathrm{~m}$ 에 이르는 기상탑을 건설하여 장기간 관측을 수행하며, 기상 탑에는 일반적으로 $10 \sim 20 \mathrm{~m}$ 간격으로 각 높이별 풍속계 및 풍향계 등의 계측센서가 설치되어 운영된다. 해상풍력의 경 우 해상기상탑 건설시 초기 건설비용이 클 뿐만 아니라 유지 보수 비용도 많이 소요된다. 해상에 위치하며 높이 $100 \mathrm{~m}$ 에 이르는 고공에 설치된 다수의 계측센서를 운영해야 하지만 해 상환경의 영향으로 적기 접근이 어렵기 때문에 유지보수가 용 이하지 않아 관측자료의 품질확보가 쉽지 않다. 특히 풍황 관 측에 일반적으로 사용되는 풍속계와 풍향계는 물리적 구동방 식으로 해상환경에서는 3 4년 이상 사용이 어려워 장기 관 측품질 확보가 더욱 어려운 실정이다.

최근 라이다(lidar; light detection and ranging) 방식의 원 격관측장비의 발달로 기상탑을 이용한 높이별 직접 관측 방 식이 점차 지상에 장비를 설치하여 레이저 광원을 이용한 원
격관측으로 대체되는 추세이다. 원격관측장비를 이용할 경우 기상탑을 건설할 필요가 없어 초기 건설비를 대폭 줄일 수 있 을 뿐만 아니라, 유지보수가 용이하고 관측성능 저하가 없어 장기간 관측품질 확보에 매우 유리하다. 다만, 사업인증 또는 타당성 평가시 요구하는 풍황관측 절차는 IEC-61400-121(IEC, 2005) 또는 Measnet(Measnet, 2016)과 같은 국제 기 준을 준용해야 하는데, IEC-61400-12-1에서는 기상탑과 컵풍 속계 등에 의한 관측기준으로 제시되어 있으며, Measnet (Measnet, 2016)에서는 원격관측장비를 사용할 경우 검증절차 를 거치도록 제시하고 있어 국내에서는 아직 라이다 장비에 대한 검증사례와 실제 사업적용 사례가 부족한 실정이다. 기 존 라이다 장비에 대한 검증 사례를 살펴보면, 육상에서 복 잡지형 영향에 따른 라이다와 기상탑 관측결과의 비교 연구 는 Schmitt et al.(2013), Kim et al.(2016) 등에 의해 수행 된 바가 있으며, 모두 자료간 일치도가 높은 결과를 보여주 었다. 또한 Kim et al.(2011)은 라이다의 고공 관측 결과를 다른 방식의 소다(sodar; sound detection and ranging) 장비 와 비교하였는데 라이다와 소다 관측결과 모두 강우 및 미세 먼지 농도와 자료 가용률간의 상관관계가 있으며, 약 $400 \mathrm{~m}$

*한국전력공사 전력연구원 (Corresponding author : Ji Young Kim, KEPCO Research Institute, 105 Munji-ro, Yuseong-gu, Daejeon, 34056, Korea, Tel: +82-42-865-5344, Fax: +82-42-865-5369, jy_kim@kepco.co.kr) 
이상의 고공에서 라이다 장비가 소다 장비에 비해 자료 가용 률과 정확도가 다소 높게 나타남을 확인하였다. Kumer et al.(2014)은 높이 $1 \mathrm{~km}$ 이상의 고공관측이 가능한 스캐닝 라이 다를 이용하여 라이오존데 결과와 비교하였는데 $125 ~ 1,325 \mathrm{~m}$ 높이 구간에서 자료간 상관도가 0.95 0.99로 나타나는 결 과를 확인한바 있다. 해상에서의 검증사례로는 Westerhellweg et al.(2010)이 독일 FINO1 해상기상탑에서 1년 관측자료 를 비교한 사례가 있으며, 높이별 관측결과가 서로 잘 일 치함을 확인하였다. 이상의 사례로 볼 때 라이다 장비 자 체의 관측품질은 타 방식과 비교해도 손색이 없는 것을 알 수 있다. 이에 본 연구에서는 윈드 라이다를 이용하여 해 상기상탑을 완전히 대체할 수 있는지에 대하여 재검증하고 자 해상환경에서 운영하기에 적합한 소형화 및 경량화되고 저전력소모를 특징으로 하는 1 차원 수직방향 측정 도플러 라이다 방식의 장비를 직접 해상기상탑 플랫폼에서 운영하 며 장비 가용률을 확인하고, 기존 기상탑과 신규 라이다의 관측결과를 상호 비교하여 각 관측결과의 정확도를 교차 검 증하고자 한다.

\section{2. 자료 및 방법}

해상기상탑과 윈드 라이다의 동시 관측결과를 비교하기 위 하여 Fig. 1과 같이 해상기상탑 해모수 1호 플랫폼에 윈드 라 이다를 설치하여 동시 관측을 수행하였으며, Table 1과 같이 자료를 확보하여 분석하였다. 해모수 1 호는 서남해 해상풍력 개발을 목적으로 전북 부안군 해역에 설치되어 2011년부터 현 재까지 운영되고 있으며, 관측시설 정보와 자료분석 사례는 $\mathrm{Ko}$ et al.(2012), Kim et al.(2015), Kim and $\operatorname{Kim}(2016)$ 등에 의 하여 소개된 바가 있다. 윈드 라이다 장비는 1차원 수직방향 으로 높이별 풍속과 풍향을 측정하는 프랑스 Leosphere사의 제품을 사용하였다. 이 장비의 주요 제원은 Table 2 와 같고 4 개의 경사빔과 1 개의 수직빔으로부터 대기 중의 에어로졸 등 의 입자 이동을 감지하여 풍속과 풍향을 측정한다. 렌즈 청 소용 와이퍼를 제외하고는 구동부가 없고 IP67의 방식 방수 처리가 되어 있어 육해상 환경 모두에서 안정적으로 장기 운 영이 가능한 것이 특징이다.

Table 1. Measurement data of HeMOSU-1 and wind lidar

\begin{tabular}{cc}
\hline \hline Period & 25 Aug. 2016 - 16 Nov. 2016 (84 days) \\
\hline Variable & $\begin{array}{c}\text { Wind speed and direction } \\
\text { (used only over } 1 \mathrm{~m} / \mathrm{s} \text { of wind speed) }\end{array}$ \\
Height (m) & $56,76,97$ above M.S.L. \\
Time interval & 10 minute average of 1 second data \\
\hline
\end{tabular}

Table 2. Specifications of wind lidar

\begin{tabular}{cc}
\hline \hline Distance range & 40 to $200 \mathrm{~m}$ of height \\
Speed range & 0 to $60 \mathrm{~m} / \mathrm{s}$ \\
Speed accuracy & $0.1 \mathrm{~m} / \mathrm{s}$ \\
Directional accuracy & $2^{\circ}$ \\
Number of heights & 12 \\
Sampling rate & $1 \mathrm{~s}$ \\
Size & $(\mathrm{L}-\mathrm{W}-\mathrm{H}) 543 \times 552 \times 540 \mathrm{~mm}$ \\
Weight & $45 \mathrm{~kg}$ \\
Power consumption & $45 \mathrm{~W}$ (nominal) \\
& $100 \mathrm{~W}$ (maximum)
\end{tabular}

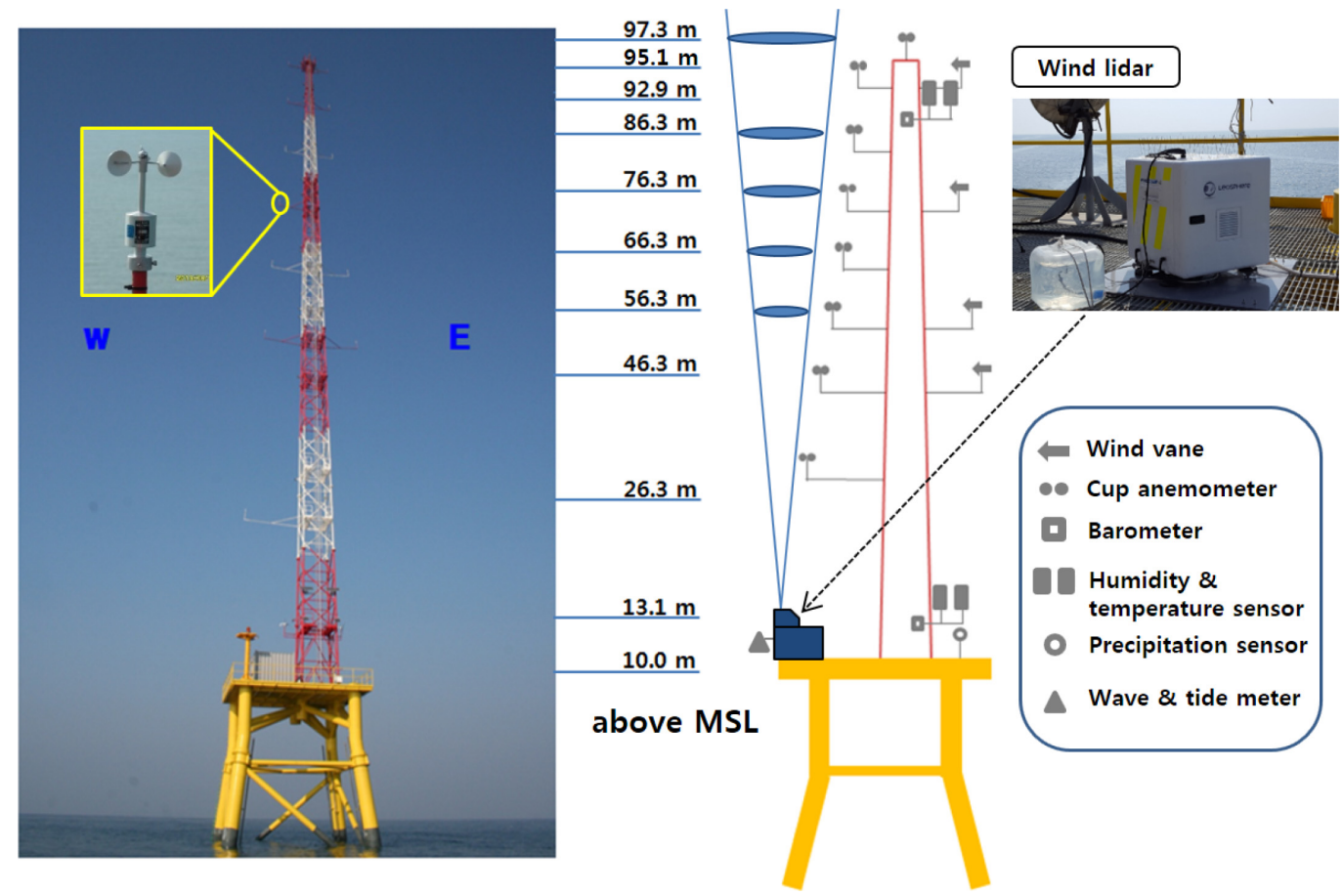

Fig. 1. HeMOSU-1 offshore met-mast and wind lidar. 


\section{3. 자료 분석}

\section{1 자료 가용률}

윈드 라이다는 원격 광학측정 장비로 대기입자의 이동속도 를 검출해야 하는 특성상 기상환경 영향에 따라 측정 자료의 가용률(또는 회수율)이 저하될 수 있는 단점이 있다. 따라서 먼 저 측정자료의 가용률을 확인하였다. 분석대상기간이 충분히 길지 않아서 계절별 영향 등 다양한 기상환경이 충분히 반영 되지 못한 부분이 있지만 약 3 개월간의 관측결과는 자료 가용 률이 충분히 확보되는 것을 확인할 수 있었다. 확보되어야할 총 자료수는 12,096 개 $(84$ 일 $\times 144$ 개/일 $)$ 이며, Fig. 2 에 나타낸바 와 같이 윈드 라이다 관측자료는 관측높이 $160 \mathrm{~m}$ 이하에서 총 11 개가 누락되어 가용률 $99.9 \%$ 로 일정하게 나타났으며, 해모 수 기상탑 자료는 모든 높이에서 $100 \%$ 확보되었음을 확인하 였다. 그리고 윈드 라이다의 경우 관측높이 $180 \mathrm{~m}$ 이상부터 가 용률이 다소 저하되었으나 최소 $99.8 \%$ 이상 확보되어 가용률 측면에서 라이다 장비만으로 기상탑 대체가 충분할 것으로 판

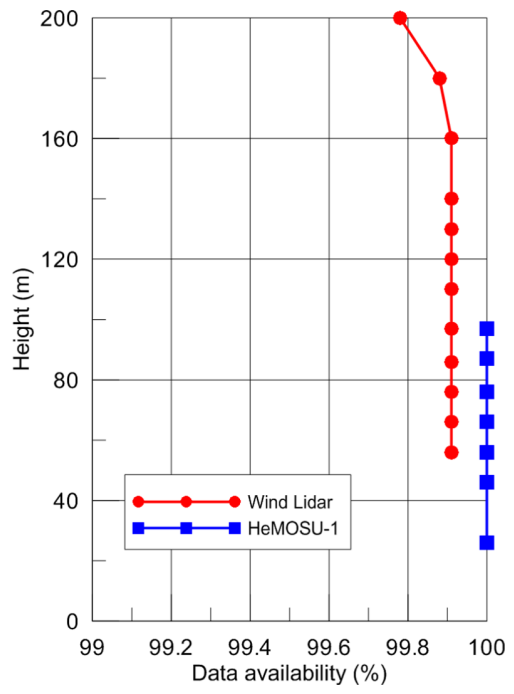

Fig. 2. Data availability at each height.

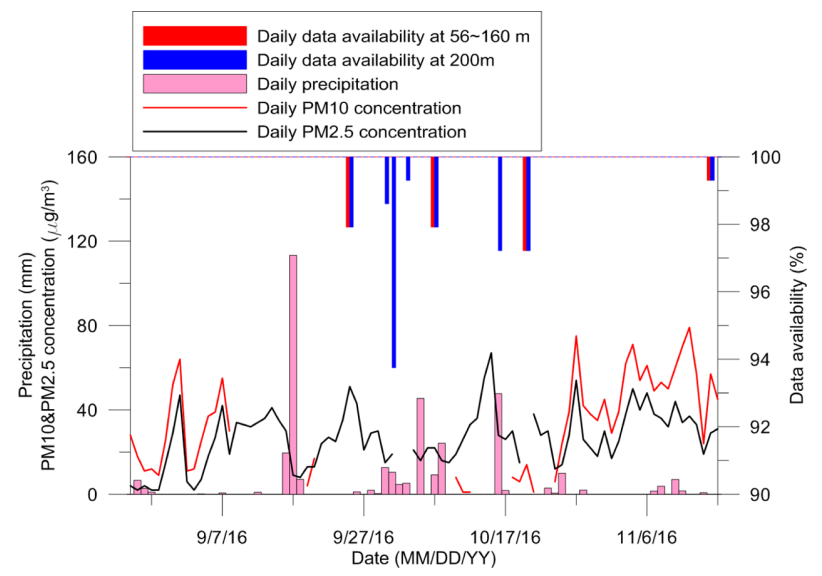

Fig. 3. Daily precipitation, PM10\&PM2.5 concentration and data availability of wind lidar.
단된다. 자료 가용률 저하 원인을 찾고자 Fig. 3 과 같이 인근 고창기상관측소의 일일 강수량 자료와 일평균 PM10 및 PM2.5 농도 자료를 라이다의 일일 자료 가용률과 함께 비교하였다. 앞서 소개한 Kim et al.(2011)의 연구결과와 달리 본 관측자료 에서는 라이다자료 가용률과 강수량 및 대기 중 미세먼지 농 도와의 상관관계를 찾기가 어려웠다. 기존 연구결과는 미세먼 지 농도가 높은 서울 도심에서 높이 $400 \mathrm{~m}$ 이상의 고층관측 에 따른 결과를 분석하였으나, 본 연구에서는 해상에서의 관 측이고 높이가 $200 \mathrm{~m}$ 이하로 한정되었으며 관측장비도 성능 이 개선된 최근 장비를 사용하였기 때문에 기존 연구와 직접 적인 비교가 어려울 수 있다. 본 연구에 이용된 PM10 농도 자 료의 경우 결측일이 많았지만 PM2.5 농도자료와 변화추이가 유사하여 결측구간이 적은 PM2.5 농도 변화에 따른 라이다 관 측자료 가용률의 변화를 비교해볼 수 있었다. 대기의 미세먼 지 농도가 라이다 관측자료의 가용률에 직접적인 영향을 준다 고 보기 어려웠으나, 관측거리가 가장 긴 높이 $200 \mathrm{~m}$ 자료를 보면 강우가 지속되어 낮은 PM 농도가 유지될 경우 자료 결 측이 발생할 가능성이 높아질 수 있음을 어느 정도 추정해볼 수 있다. 이에 대해서는 보다 장기 관측자료를 수집하여 분석 할 필요가 있겠다. 이상과 같이 원격관측장비 특성상 대기조 건에 따라서 자료의 가용률이 저하될 수 있으나 관측기간 중 에는 높이 $160 \mathrm{~m}$ 이하에서 일자료 가용률이 $97 \%$ 이상을 유 지하며 전반적으로 자료 결측 가능성이 매우 낮아 윈드 라이 다 장비의 단독 활용성은 충분한 것으로 보인다.

\section{2 기상탑 구조물 차폐 영향}

기상탑에 풍향.풍속계를 설치할 때 기상탑 구조물에 의해 풍 속이 교란되는 차폐영향을 최소화하도록 일정기준 이상의 붐 대를 이용하여 풍향.풍속계가 기상탑 구조물로부터 충분한 이 격거리를 갖도록 해야 한다. 그럼에도 불구하고 구조물 차폐영 향을 완전히 배제할 수 없기 때문에 기상탑 관측결과는 이로 인한 측정오차를 일부 내포하고 있다. 반면 윈드 라이다와 같 은 원격장비를 이용할 경우 탑구조물이 존재하지 않기 때문에 차폐영향을 받지 않는 장점이 있다. 본 연구에서는 라이다 자 료를 이용하여 기상탑 관측자료의 차폐영향 정도를 파악해 보 았다. 해모수 1 호의 기상탑 평면구조는 Fig. 4 와 같이 설계 및 제작되어 있다. 주풍향 방향에서 차폐영향을 받지 않도록 서편 에 풍속계가 위치하고 있으며 동풍계열의 바람이 불 경우 구 조물에 의한 차폐영향을 받게 된다. 단, $97 \mathrm{~m}$ 풍속계는 차폐영 향을 배제하기 위하여 기상탑 최상단에 설치되었다. Fig. 5는 각 높이에서 측정 풍향별 기상탑 풍속대비 라이다 풍속비를 나 타내며, 높이 $56 \mathrm{~m}$ 와 $76 \mathrm{~m}$ 결과를 보면 역시 동풍계열의 바람 이 불 경우 기상탑 차폐영향으로 기상탑 풍속이 약 $20 ~ 60 \%$ 감 소되는 것을 확인할 수 있다. 따라서 이하 비교 분석에서는 높 이 $56 \sim 76 \mathrm{~m}$ 에서는 차폐영향 방위각구간을 $70^{\circ} \sim 120^{\circ}$, 높이 $97 \mathrm{~m}$ 에서는 $162^{\circ} \sim 170^{\circ}$ 로 설정하여 구간 내에 있는 자료를 포 함하는 경우와 제거한 경우에 대하여 분석하였다. 


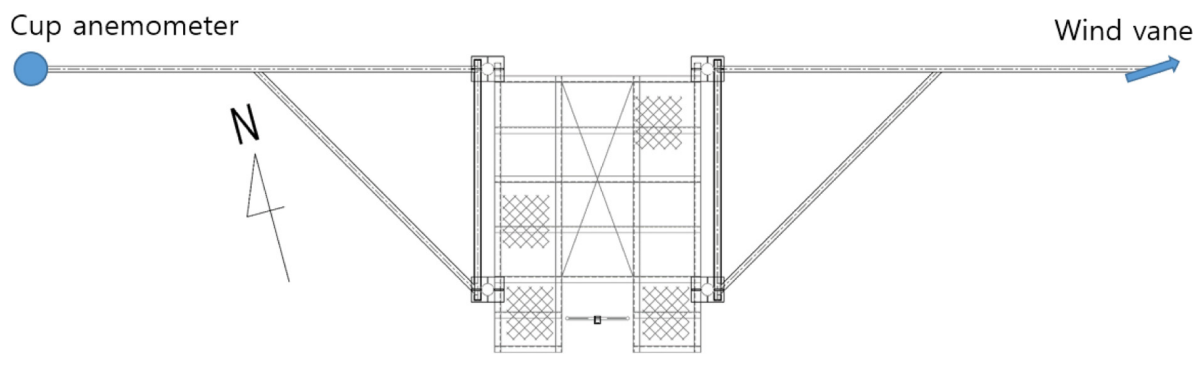

Fig. 4. Plane structure of HeMOSU-1 mast(@76 m).

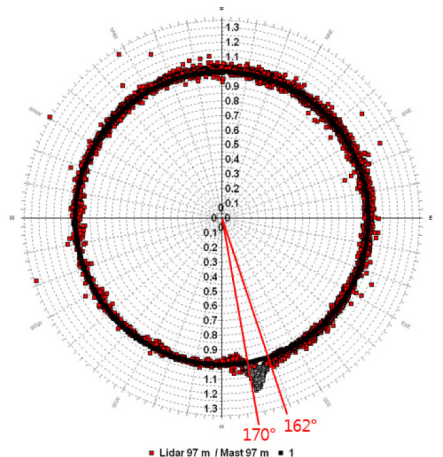

(a) $97 \mathrm{~m}$

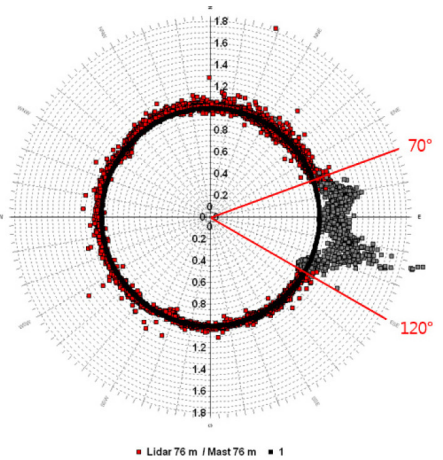

(b) $76 \mathrm{~m}$

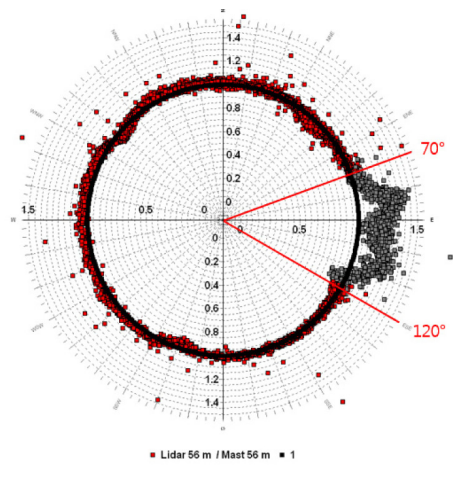

(c) $56 \mathrm{~m}$

Fig. 5. Ratio of lidar wind speed to HeMOSU-1 mast wind speed at each wind direction and height.

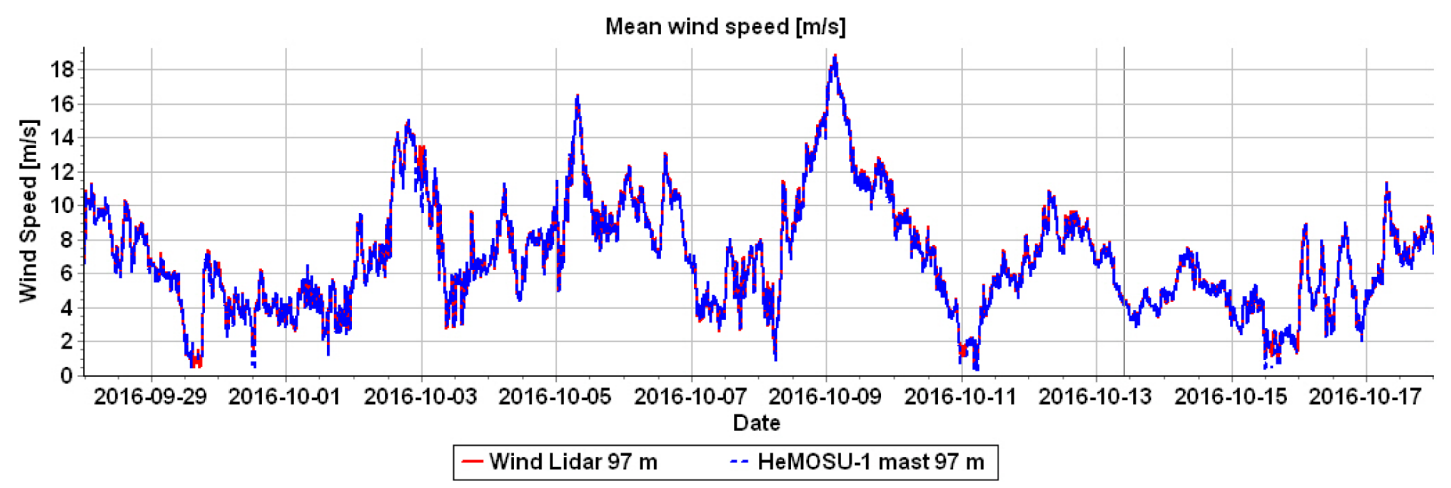

Fig. 6. Time series of measured wind speed of wind lidar and HeMOSU-1 mast.

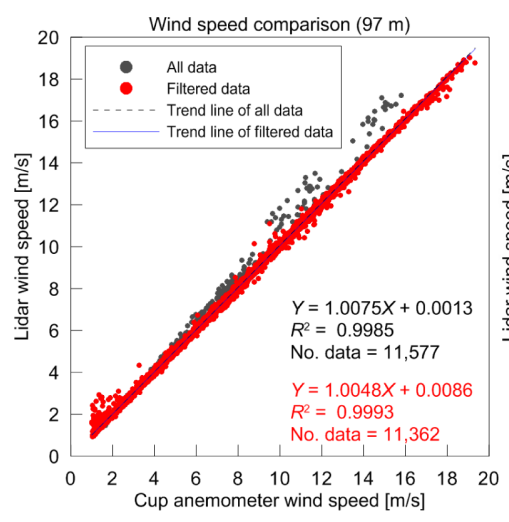

(a) $97 \mathrm{~m}$

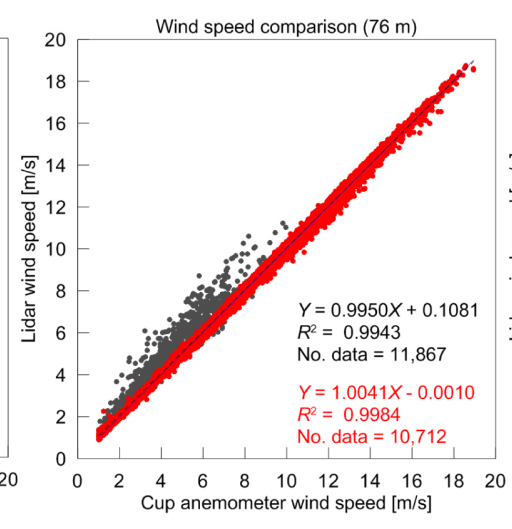

(b) $76 \mathrm{~m}$

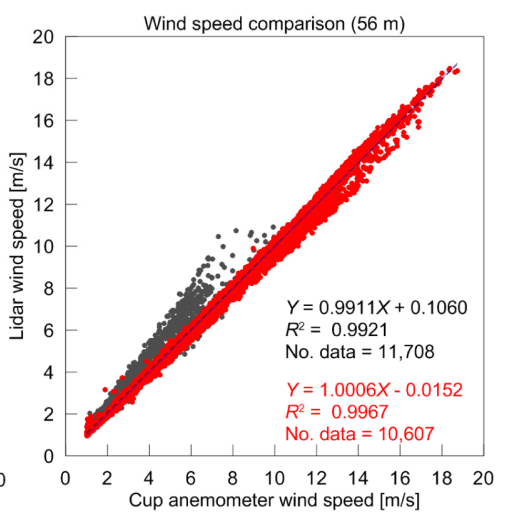

(c) $56 \mathrm{~m}$

Fig. 7. Comparison of wind speed measurement between lidar and HeMOSU-1 mast (black: all data, red: excluding shaded data). 


\section{3 풍속 비교}

Fig. 6은 높이 $97 \mathrm{~m}$ 에서의 윈드 라이다와 해모수 1호 풍속 계에서 관측된 10 분 평균풍속의 시계열 일부 구간을 보여주 는 것으로 두 자료가 거의 일치하는 것으로 보인다. 정량적 비교를 위하여 Fig. 7과 같이 x-y plot을 통해 풍속크기별 적 합도를 보면 모든 자료를 포함하는 경우 결정계수 $R^{2}$ 가 높이 별로 $0.9921,0.9943,0.9985$ 로 나타났고, 구조물 차폐영향을 받는 구간의 자료를 제외할 경우 $0.9967,0.9984,0.9993$ 로 나타나 두 자료가 잘 일치하는 것을 알 수 있다. Table 3은 풍속자료 전체기간의 평균과 표준편차를 나타내는 것으로, 차 폐영향을 받는 자료를 포함하는 경우 라이다와 기상탑 풍속계
간의 평균풍속비가 $99.0 \sim 99.3 \%$ 범위로 나타났으며, 차폐영향 자료를 제외한 경우 평균풍속비가 $99.4 \sim 100 \%$ 로 나타났다. 차 폐영향 자료를 제외할 경우 $56 \sim 76 \mathrm{~m}$ 의 경우 차폐영향을 받 은 저풍속 자료가 많이 제외되어 평균풍속이 $97 \mathrm{~m}$ 결과보다 크게 나타났으며, 자료간 차이도 더욱 감소하였다. 표준편차 비는 차폐영향 자료를 배제하지 않아도 두 자료간의 차이가 매우 작았으며, 차폐영향 자료를 배제하였을 때 그 차이가 보 다 감소하였다.

\section{4 난류강도 비교}

풍력 개발을 목적으로 풍황 관측시에는 기기 피로하중 산

Table 3. Comparison of mean and standard deviation of wind speed

\begin{tabular}{|c|c|c|c|c|c|c|c|}
\hline & \multirow{2}{*}{$\begin{array}{l}\text { Height } \\
(\mathrm{m})\end{array}$} & \multicolumn{3}{|c|}{ All data } & \multicolumn{3}{|c|}{ Excluding shaded data } \\
\hline & & $\begin{array}{l}\text { Mast } \\
\text { (a) }\end{array}$ & $\begin{array}{l}\text { Lidar } \\
\text { (b) }\end{array}$ & $\begin{array}{l}\text { Ratio } \\
\text { (a)/(b) }\end{array}$ & $\begin{array}{l}\text { Mast } \\
\left(a^{\prime}\right)\end{array}$ & $\begin{array}{l}\text { Lidar } \\
\left(b^{\prime}\right)\end{array}$ & $\begin{array}{l}\text { Ratio } \\
\left(a^{\prime}\right) /\left(b^{\prime}\right)\end{array}$ \\
\hline \multirow{3}{*}{$\begin{array}{l}\text { Mean wind speed } \\
\qquad(\mathrm{m} / \mathrm{s})\end{array}$} & 97 & 6.86 & 6.91 & 0.993 & 6.84 & 6.88 & 0.994 \\
\hline & 76 & 6.62 & 6.69 & 0.990 & 6.89 & 6.90 & 0.999 \\
\hline & 56 & 6.57 & 6.62 & 0.992 & 6.83 & 6.82 & 1.001 \\
\hline \multirow{3}{*}{$\begin{array}{l}\text { Standard deviation } \\
\qquad(\mathrm{m} / \mathrm{s})\end{array}$} & 97 & 3.69 & 3.71 & 0.995 & 3.60 & 3.61 & 0.997 \\
\hline & 76 & 3.72 & 3.71 & 1.003 & 3.73 & 3.74 & 0.997 \\
\hline & 56 & 3.59 & 3.57 & 1.006 & 3.65 & 3.67 & 0.995 \\
\hline
\end{tabular}

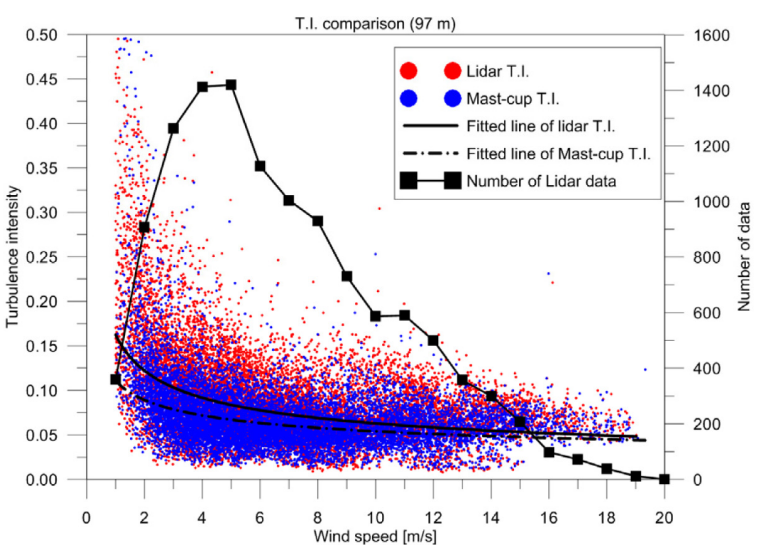

(a) $97 \mathrm{~m}$

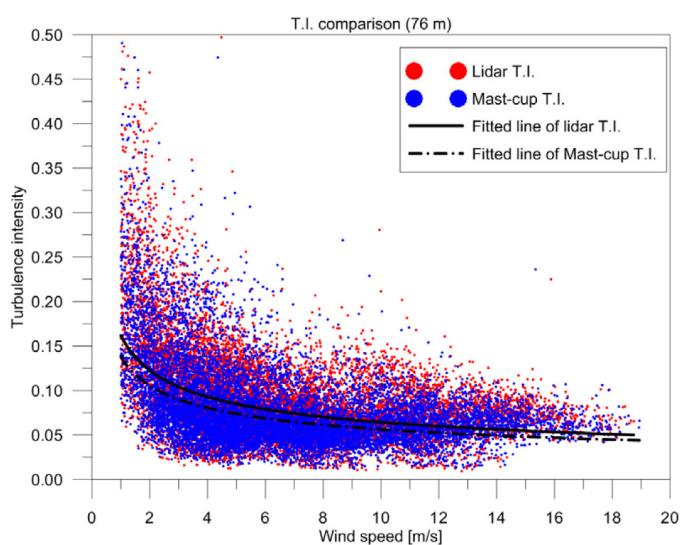

(b) $76 \mathrm{~m}$

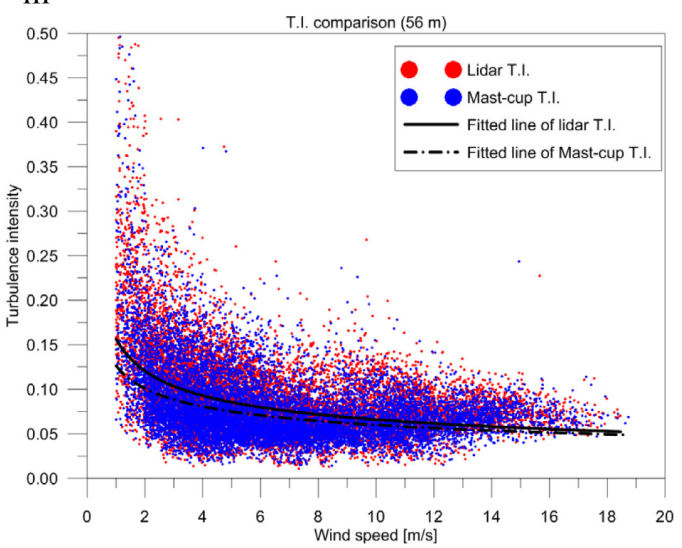

(c) $56 \mathrm{~m}$

Fig. 8. Comparison of turbulence intensity between HeMOSU-1 mast and lidar. 


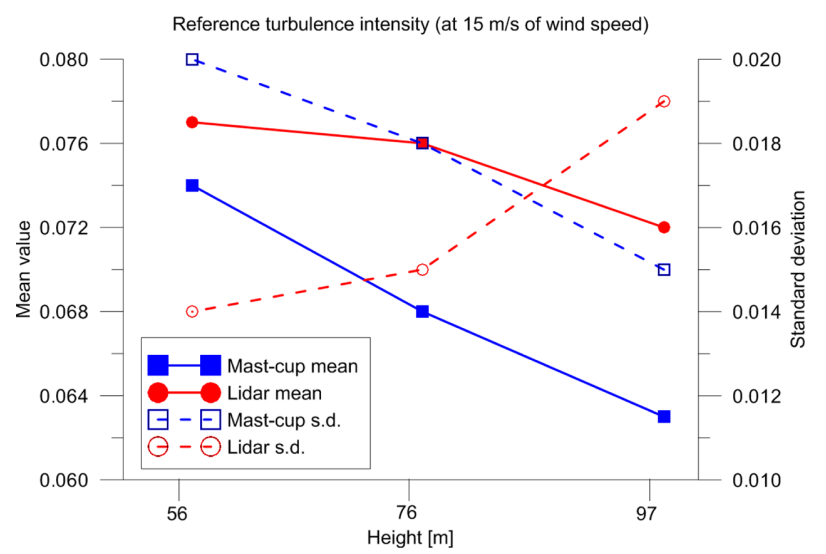

Fig. 9. Mean and standard deviation of turbulence intensity at $15 \mathrm{~m} / \mathrm{s}$ of wind speed.

출을 위하여 식(1)과 같은 평균풍속에 대한 풍속 표준편차의 비로 나타내는 난류강도를 관측해야 한다.

$$
I=\sigma / \bar{u}
$$

여기서, $I$ 는 난류강도, $\sigma$ 는 풍속 표준편차, $\bar{u}$ 는 풍속 평균
을 나타내며, 본 연구에서는 1 초 관측자료의 10 분단위 표준 편차와 평균을 이용하였다. Fig. 8은 기상탑 풍속계와 윈드 라이다로부터 산출한 난류강도를 풍속크기별로 도시하여 비 교한 것으로, 윈드 라이다를 통해 관측된 난류강도가 다소 크 게 나타났다. Table 3 에 나타내었던 풍속 표준편차의 전체 평 균치는 두 자료간의 차이가 거의 없었으나, 난류강도로 산출 할 경우 차이가 나타났다. 풍력터빈 적용규격을 판별하는 기 준인 풍속 $15 \mathrm{~m} / \mathrm{s}$ 에서의 난류강도를 비교해보면 Fig. 9와 같 이 나타나는데, 평균치가 높이에 따라 0.003 에서 0.009 정도 로 윈드 라이다 관측치가 크게 나타났으나 그 차이는 미미한 수준이다. 낮은 높이일수록 그 차이가 감소하였으나 오히려 기 상탑 관측결과가 낮은 높이에서 보다 왜곡되어 나타난 경향 으로 추정된다. 평균 난류강도는 두 자료 모두 관측높이가 낮 아질수록 감소하는 경향을 보였으나, 표준편차의 경우 서로 상 반된 경향을 보였다. 기준이 되는 참값을 확인할 수가 없어 어 떤 결과가 보다 정확한 자료인지 판단하기는 어렵다.

\section{5 풍향 비교}

관측 풍향을 Fig. 10 12 및 Table 4와 같이 비교하였다. Fig. 10은 12개 방위별 출현율을 나타내는 바람장미도이며 두

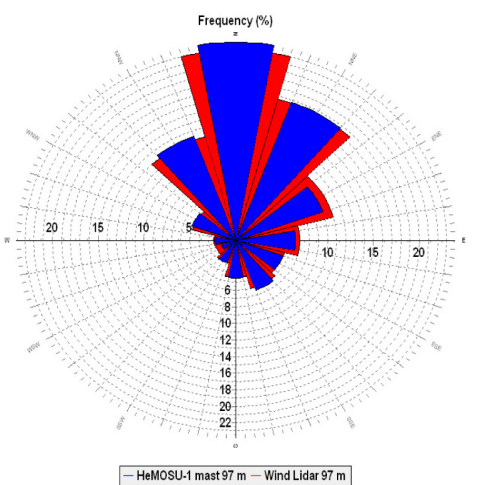

(a) $97 \mathrm{~m}$

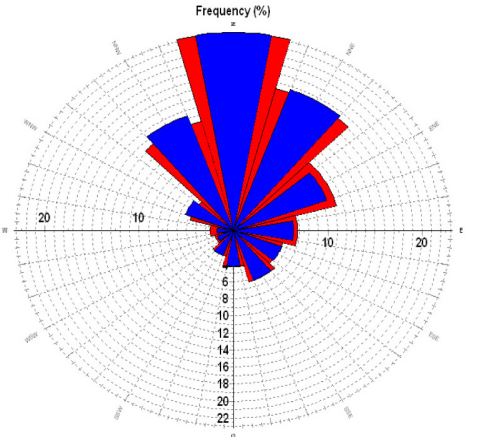

- HeMOSU.1 mast76 $\mathrm{m}-$ Wind Lidar $76 \mathrm{~m}$

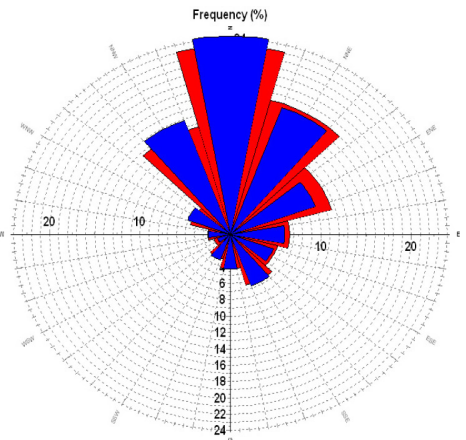

- HeMOSU-1 mast $56 \mathrm{~m}-$ Wind Lidar $56 \mathrm{~m}$

(c) $56 \mathrm{~m}$

Fig. 10. Comparison of wind direction frequency between HeMOSU-1 mast and lidar.

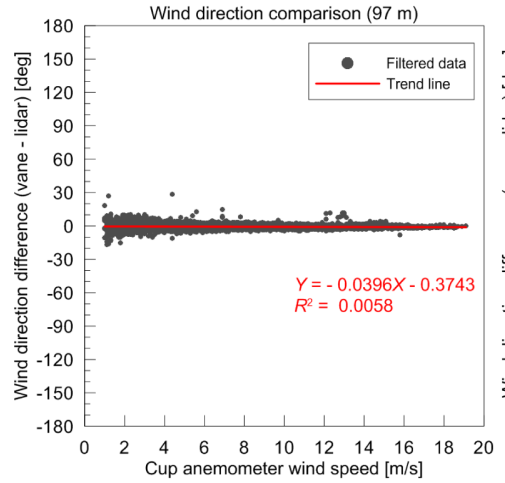

(a) $97 \mathrm{~m}$

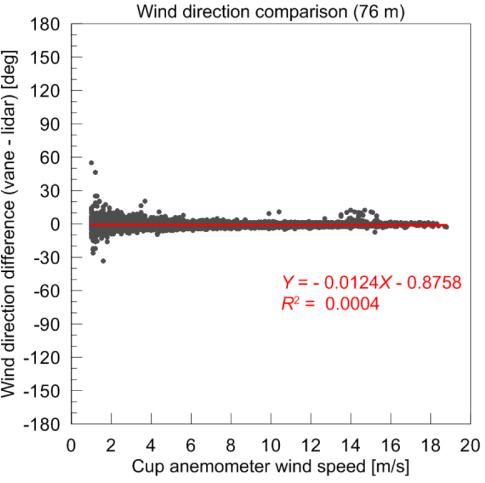

(b) $76 \mathrm{~m}$

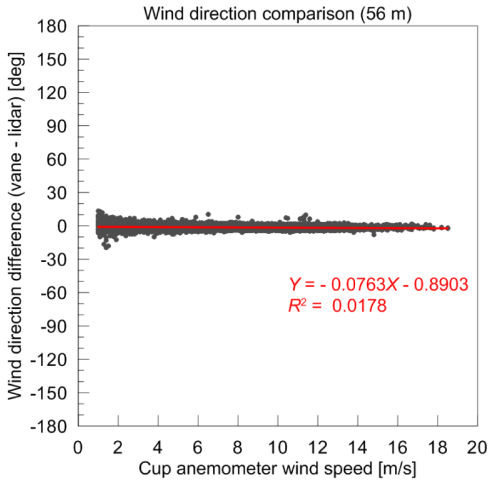

(c) $56 \mathrm{~m}$

Fig. 11. Wind direction difference between HeMOSU-1 mast and lidar versus wind speed. 


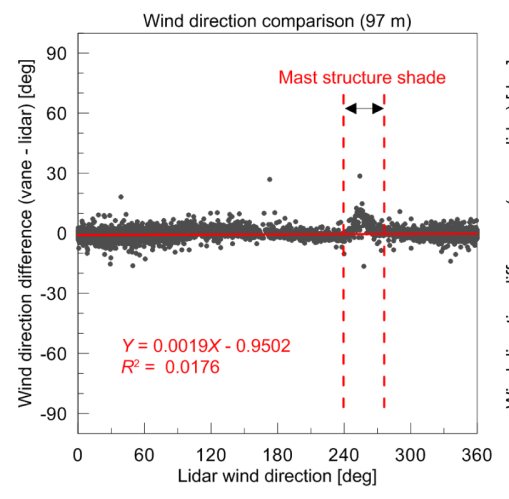

(a) $97 \mathrm{~m}$

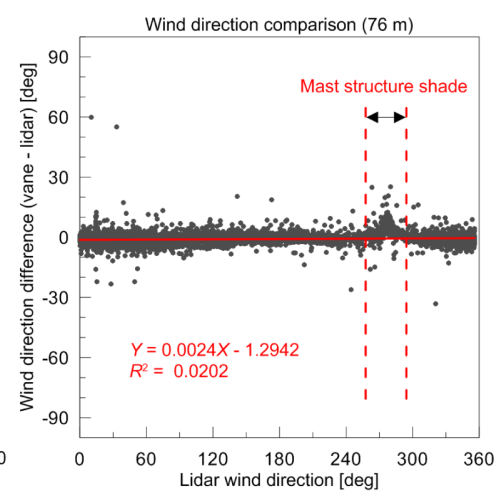

(b) $76 \mathrm{~m}$

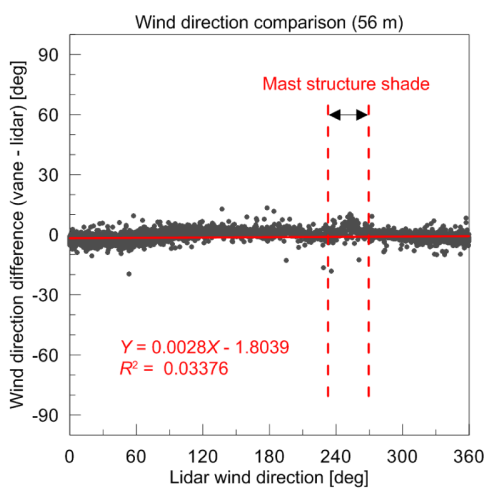

(c) $56 \mathrm{~m}$

Fig. 12. Wind direction difference between HeMOSU-1 mast and lidar versus wind direction.

Table 4. Mean wind direction difference between HeMOSU-1 mast and lidar at each height $\left(\varepsilon_{\text {dir. }}\right.$ : wind direction difference (vane-lidar))

\begin{tabular}{ccc}
\hline \multirow{2}{*}{ Height $(\mathrm{m})$} & \multicolumn{2}{c}{ Wind direction difference } \\
\cline { 2 - 3 } & Mean $\varepsilon_{\text {dir. }}$ & Mean $\left|\varepsilon_{\text {dir. }}\right|$ \\
\hline 97 & -0.64 & 1.47 \\
76 & -0.96 & 1.61 \\
56 & -1.39 & 2.06 \\
\hline
\end{tabular}

자료가 거의 유사한 경향을 보이고 있으나 약간의 차이는 보 이고 있다. 보다 정량적인 비교를 위하여 Fig. 11과 같이 각 풍속크기별 두 관측풍향간의 편차를 산출하였으며, 3 개 높이 에서 공통적으로 저풍속구간에서 편차가 다소 크게 나타나고 풍속 12 $14 \mathrm{~m} / \mathrm{s}$ 구간에서 기상탑 풍향계가 다소 크게 관측 되는 경향이 나타났다. 저풍속 구간에서 풍향편차가 크게 나 타나는 것은 기상탑의 풍향계(wind vane) 특성에서 기인된다 고 볼 수 있다. Fig. 8에 나타낸 풍속구간별 난류강도의 크 기 분포와 같이 저풍속 구간에서 풍속의 변동성이 크고 풍속 이 클수록 풍향계의 변동성도 작아진다는 점과 연관지을 수 있다. 풍속 $12 \sim 14 \mathrm{~m} / \mathrm{s}$ 구간에서 양의 편차를 보이는 것은 Fig. 12에서 보듯이 기상탑 구조물 차폐 영향으로 기상탑 풍 향계의 측정오차로부터 비롯된 것을 알 수 있다. Fig. 12는 각 방위별 두 풍향 관측자료간의 편차를 표시한 그림으로, 3 개 높이 모두에서 $270^{\circ}$ 전후 구간에서 양의 편차를 보이고 있 다. 기상탑 첨두 수직붐대에는 풍속계만 설치되어 높이 $97 \mathrm{~m}$ 관측자료 분석 시 풍속은 $97 \mathrm{~m}$ 풍속계 관측자료를 사용하고 풍향은 높이 $95 \mathrm{~m}$ 에 설치된 풍향계 자료를 사용하였기 때문 에 $97 \mathrm{~m}$ 자료 역시 다른 높이와 마찬가지로 서편에 위치한 기 상탑 구조물의 차폐 영향을 받는 것을 확인할 수 있다. Table 4 는 관측풍향간의 평균 편차로, 전체 편차의 평균치와 각 시 점별 편차의 절대값에 대한 평균치를 보여준다. 평균 풍향편 차가 1 20정도로 풍향계 자체 정밀도 범위 내 수준으로 매우 양호한 결과임을 알 수 있으며, 낮은 높이일수록 편차가 크게 나타나는데 기상탑 구조물의 영향에 의한 것으로 보인다.

\section{4. 결 론}

본 연구에서는 풍력 개발 시 요구되는 특정 고도의 풍황 관 측을 기존 기상탑 대신 원격관측장비인 윈드 라이다를 이용하 여 수행하기 위하여 해상에서의 관측결과를 비교하였다. 기상탑 의 경우 구조물 차폐영향에 의한 관측오차가 발생되며, 자료분 석시 이러한 자료를 배제하여 분석함으로써 정확도를 향상시킬 필요가 있으나, 윈드 라이다를 이용할 경우 풍속 및 풍향의 크 기, 편차, 경향 등에 있어 기존 기상탑 풍향-풍속계와 거의 동일 한 수준의 관측결과를 얻을 수 있으며, 구조물에 의한 차폐영향 이 없는 보다 정확한 결과를 얻을 수 있음을 확인하였다. 또한 윈드 라이다 자료를 이용하여 기상탑의 차폐 영향에 의한 자료 오차 발생정도를 정량적으로 파악할 수 있었다. 자료 가용률 측 면에서도 관측높이별로 차이가 없이 우수한 성능을 보이며, 기 상환경 영향에 의한 자료 결측이 거의 나타나지 않아 원격관측 방식의 한계점 또한 보이지 않았다. 다만 본 연구결과는 이용 자 료의 기간이 3 개월 정도밖에 되지 않아 1 년 이상의 장기간 자 료를 확보하여 계절영향 및 대기환경 조건 등에 따른 자료 가 용률 변화 등에 관한 보다 심도 있는 연구가 필요해 보인다. 그 러나 이상의 결과만으로도 향후 높이별 풍황 관측 시 윈드 라 이다가 기상탑을 충분히 대체할 수 있을 것으로 판단되며 보다 경제적이고 효율적인 관측을 수행할 수 있을 것으로 기대된다.

\section{감사의 글}

본 연구는 산업통상자원부의 재원으로 한국에너지기술평가 원(KETEP)이 지원한 “서남해 $2.5 \mathrm{GW}$ 해상풍력 개발을 위한 실증단계 연구(No. 2011T100100307)" 과제 및 한국전력공사 가 지원한 “해상기상탑 대체를 위한 연직 도플러 라이다 적 용성 검증 연구” 과제에 의해 수행되었습니다.

\section{References}

IEC (2005). IEC 61400-12-1: Wind turbines - Power performance 
measurements of electricity producing wind turbines, Edition 1.0.

Kim, D., Kim, T., Oh, G., Huh, J. and Ko, K. (2016). A comparison of ground-based LiDAR and met mast wind measurements for wind resource assessment over various terrain conditions. Journal of Wind Engineering and Industrial Aerodynamics, 158, 109-121.

Kim, H.-G., Kim, D.-H., Jeon, W.-H. and Choi, H.-J. (2011). Comparative validation of WindCube LIDAR and Scintec SODAR for wind resource assessment - Remote sensing campaign at Jamsil. New \& Renewable Energy, 7(2), 43-50.

Kim, J.-Y. and Kim, K.-Y. (2016). Reconstructing long-term wind data at an offshore met-mast location using cyclostationary empirical orthogonal functions. Journal of Wind Engineering and Industrial Aerodynamics, 156, 146-158.

Kim, M. S., Kim, J. Y., Kwak, J. Y. and Kang, K. S. (2015). Analysis of working time at the test site of southwest offshore wind project in Korea based on weather window. Journal of Korean Society of Coastal and Ocean Engineers, 27(5), 358-363.

Ko, D. H., Jeong, S. T., Cho, H., Kim, J. Y. and Kang, K. S. (2012). Error analysis on the offshore wind speed estimation using
HeMOSU-1 data. Journal of Korean Society of Coastal and Ocean Engineers, 24(5), 326-332.

Kumer, V.-M., Reuder, J. and Furevik, B. R. (2014). A comparison of LiDAR and radiosonde wind measurements. Energy Procedia, 53, 214-220.

Measnet (2016). Evaluation of site-specific wind conditions, Version 2.

Schmitt, C., Wagner, L. and Boquet, M. (2013). Measuring wind profiles in complex terrain using doppler wind LiDAR systems with FCR ${ }^{\mathrm{TM}}$ and CFD implementations. EWEA 2013.

Westerhellweg, A., Canadillas, B., Beeken, A. and Neumann, T. (2010). One year of lidar measurements at FINO1-Platform: Comparison and verification to met-mast data. 10th German Wind Energy Conference DEWEK 2010.

Received 7 February, 2017

Revised 13 February, 2017

Accepted 14 February, 2017 